\title{
Prevalence of Ocular Diseases at University Teaching Hospital of Kara in Togo
}

\section{Kokou Messan Amedome ${ }^{1}$, Codjo Rodrigue Abel Assavedo ${ }^{2 *}$, Kokou Vonor $^{3}$, Nidain Maneh ${ }^{4}$, Didier Koffi Ayena ${ }^{5}$ and Komi Balo ${ }^{6}$}

${ }^{1}$ University Teaching Hospital of Kara, Togo

${ }^{2}$ Ophthalmology Teaching and Research Unit, Department of Surgery and Surgical

Specialties, Faculty of Medicine, University of Parakou, Benin

${ }^{3}$ Regional Hospital of Kara Tomdè, Togo

${ }^{4}$ University Teaching Hospital of Lomé Campus, Togo

${ }^{5}$ University Teaching Hospital of Sylvanus Olympio, Togo

${ }^{6}$ Sight and Vision Eye Clinic of Lomé, Avénou, Togo

*Corresponding Author: Codjo Rodrigue Assavedo, Ophthalmology Teaching and Research Unit, Department of Surgery and Surgical Specialties, Faculty of Medicine, University of Parakou, Benin.
Received: December 27, 2021

Published: January 17, 2022

(C) All rights are reserved by Kokou Messan Amedome., et al.

\begin{abstract}
Purpose: The aim of our study was to list the common eye conditions encountered in hospital practice at CHU Kara in order to determine their prevalence.

Patients and Methods: This was a retrospective and descriptive study based on the files of patients who consulted in the ophthalmology department of CHU Kara from January 1, 2017 to December 31, 2019. From a target population of 550 patients, we retained 248 selected cases of conjunctivitis who underwent a complete ophthalmologic examination. The parameters studied were age, sex, profession, reason for consultation and diagnosis.

Results: The sample consisted of 550 patients. The average age was 34.63 years +/- 19.68. The 50 and over age group accounted for $40.55 \%$. The sex ratio was 1.07 . The visual loss represented $25.55 \%$ of the reasons for consultation. The eye conditions commonly encountered were conjunctivitis followed by ametropia then cataracts and glaucoma, ie $45.09 \%$ respectively; $28.18 \% ; 15.63 \%$ and 9.45\%. Retinal conditions such as retinal detachment accounted for $0.55 \%$ of all conditions encountered.
\end{abstract}

Conclusion: Our study confirms the predominance of conjunctivitis in hospital practice in our context. However, other ailments should not be neglected since they are sources of visual impairment that can impact the development of our societies.

Keywords: Prevalence; Eye Conditions; Conjunctivitis; Ametropia

\section{Introduction}

The Vision 2020 Global Initiative - the right to sight, aimed at eliminating preventable blindness, prioritizes blinding eye diseases such as cataracts, trachoma, glaucoma and retinal diseases, $90 \%$ of which occur in countries with low income. While this focus on visual impairment has led to strong collaborations and a drive to reduce blindness; other eye conditions, which can affect the functionality and quality of life of individuals and may cause people to seek care but do not necessarily lead to blindness, have been overlooked. Therefore, the epidemiology and impact of many non-blinding eye diseases have not been adequately studied [1]. In addition, according to the World Health Organization, eye conditions affect at least 2.2 billion people worldwide. These people are 
said to be visually impaired or blind, of whom at least 1 billion have a condition that could have been prevented or remains untreated. Recent studies of eye health human resources in sub-Saharan Africa and Latin America have confirmed these patterns of misallocation and the manager's inability to track population rates [2-5]. In sub-Saharan Africa, the reduced number of ophthalmologists and the difficulties in obtaining basic data on health indicators are factors that limit knowledge of the distribution of eye diseases in these populations. Thus, epidemiological data on eye diseases in the general population in Togo, for example, would be less numerous. The diagnosis and adequate management of these conditions give rise to growing needs which are less and less met. Eye disorders therefore constitute a real major public health issue, hence the need for epidemiological data within the general population in Togo. Thus the objective of our was to show the prevalence of different eye conditions at the university hospital of Kara in Togo.

\section{Patients and Methods}

This was a retrospective and descriptive cross-sectional study from January 1, 2017 to December 31, 2019. All the files of patients who consulted in the ophthalmology department of University Teaching Hospital of Kara during the study period were included in this study. All incomplete files were excluded from this study. The parameters studied were data from civil status and clinical examination. Data collection was done using a pre-established data collection sheet. The different ailments during our study were labeled according to the criteria of the International Classification of Diseases in its $10^{\text {th }}$ version.

The analysis and processing of the data collected were carried out using the Epi info 7.1.5 software and Excel version 2013.

\section{Results}

\section{Socio-demographic characteristics}

A total of 550 files were collected during the study period. The sex ratio was 0.93 . The mean age was 34.63 years with a standard deviation of 19.68. The distribution of patients according to the different age groups is shown in table 1 . Subjects over 40 years old accounted for $40.55 \%$.

Pupils and students represented $29.40 \%$ as shown in table 2 .

\begin{tabular}{|l|c|c|}
\hline Age & Size & Perrcentage (\%) \\
\hline$[0-9$ years $]$ & 56 & 10.18 \\
\hline$[10-19$ years $]$ & 95 & 17.27 \\
\hline$[20-29$ years $]$ & 88 & 16.00 \\
\hline$[30-39$ years $]$ & 88 & 16.00 \\
\hline$[40$ and over $]$ & 223 & 40.55 \\
\hline Total & 550 & 100.00 \\
\hline
\end{tabular}

Table 1: Distribution of patients by age.

\begin{tabular}{|l|c|c|}
\hline Profession & Size & Percentage \\
\hline State worker & 132 & $24.10 \%$ \\
\hline Household & 66 & $12.00 \%$ \\
\hline Trader & 27 & $4.90 \%$ \\
\hline Farmer & 20 & $3.60 \%$ \\
\hline Worker & 45 & $8.20 \%$ \\
\hline Pupil/student & 161 & $29.40 \%$ \\
\hline No occupation & 28 & $5.10 \%$ \\
\hline Others & 60 & $10.90 \%$ \\
\hline Unspecified & 9 & $1.60 \%$ \\
\hline Total & 548 & $100.00 \%$ \\
\hline
\end{tabular}

Table 2: Distribution of patients by socio-professional groups.

\section{Reasons for consultation}

Patients complained of reduced visual acuity in 25.55 of cases and eye pain in $25.08 \%$ of cases. The distribution of patients according to the reason for consultation is summarized in table 3.

\begin{tabular}{|c|c|c|}
\hline Reasons for consultation & Yes & Percentage \\
\hline Eye pain & 158 & $25.08 \%$ \\
\hline Eye pruritus & 108 & $17.14 \%$ \\
\hline Tearing & 40 & $6.35 \%$ \\
\hline Decreased visual acuity & 161 & $25.55 \%$ \\
\hline Eye redness & 65 & $10.32 \%$ \\
\hline Tingling & 40 & $6.35 \%$ \\
\hline Eye trauma & 58 & $9.21 \%$ \\
\hline Total & 630 & $100.00 \%$ \\
\hline
\end{tabular}

Table 3: Distribution of patients according to the reasons for consultation. 
Ophthalmologic history

In 42 patients, we noted an ophthalmologic history, including ametropia and glaucoma as shown in table 4.

\begin{tabular}{|l|c|c|}
\hline & Size & Percentage \\
\hline Ametropia & 20 & $3.60 \%$ \\
\hline Glaucoma & 8 & $1.50 \%$ \\
\hline Cataract & 6 & $1.10 \%$ \\
\hline Eye trauma & 5 & $0.90 \%$ \\
\hline Hypotonizing treatment & 1 & $0.20 \%$ \\
\hline Retinal detachment & 1 & $0.20 \%$ \\
\hline Operated for a pterygium & 1 & $0.20 \%$ \\
\hline Total & 42 & $7.63 \%$ \\
\hline
\end{tabular}

Table 4: Distribution of patients according to ophthalmologic history.

Ocular pathologies encountered

Several eye pathologies were diagnosed including: ametropia (28.18\%), conjunctivitis (45.09\%), cataracts (15.63\%), glaucoma $(9.45 \%)$ as shown in table 5 .

Eye pathologies according to gender

Conjunctivitis and ametropia were represented predominantly in women as shown in table 6.

Ocular pathologies encountered according to age groups

Several pathologies were encountered during this study. Certain pathologies such as conjunctivitis have been found predominantly in younger subjects while others such as cataracts are found in el-

\begin{tabular}{|l|c|c|}
\hline Diagnostics & Effectif & Pourcentage (\%) \\
\hline Ametropia & 155 & 28.18 \\
\hline Chalazion & 3 & 0.55 \\
\hline Conjunctivitis & 248 & 45.09 \\
\hline Episcleritis & 3 & 0.55 \\
\hline Cataract & 86 & 15.63 \\
\hline Glaucoma & 52 & 9.45 \\
\hline Retinal detachment & 3 & 0.55 \\
\hline Total & 550 & 100 \\
\hline
\end{tabular}

Table 5: Distribution of patients according to ophthalmological conditions.

\begin{tabular}{|l|c|c|c|}
\hline & Male & Female & Total \\
\hline Ametropia & 65 & 90 & 155 \\
\hline Chalazion & 3 & 0 & 3 \\
\hline Conjunctivitis & 98 & 150 & 248 \\
\hline Episcleritis & 1 & 2 & 3 \\
\hline Cataract & 47 & 39 & 86 \\
\hline Glaucoma & 26 & 26 & 52 \\
\hline Others* & 2 & 1 & 3 \\
\hline Total & 244 & 311 & 550 \\
\hline
\end{tabular}

Table 6: Distribution of pathologies according to sex.

Others*: Retinal detachment, eye trauma, pterygium.

derly subjects. The distribution of the different pathologies according to the age group is summarized in table 7.

\begin{tabular}{|l|c|c|c|c|c|c|c|c|}
\hline $\begin{array}{l}\text { Pathologies } \\
\text { Age groups } \\
\text { (years) }\end{array}$ & Ametropia & Chalazion & Conjunctivitis & Episcleritis & Cataract & Glaucoma & Others & Total \\
\hline Less than 1 & 0 & 0 & 8 & 0 & 0 & 0 & 0 & 8 \\
\hline 1 to 9 & 9 & 0 & 32 & 0 & 0 & 2 & 0 & 43 \\
\hline 10 to 19 & 40 & 1 & 49 & 0 & 0 & 10 & 1 & 101 \\
\hline 20 to 29 & 24 & 1 & 44 & 2 & 0 & 7 & 0 & 78 \\
\hline 30 to 39 & 22 & 0 & 38 & 1 & 2 & 5 & 1 & 69 \\
\hline 40 to 49 & 10 & 0 & 10 & 0 & 14 & 6 & 0 & 40 \\
\hline 50 to 59 & 16 & 1 & 20 & 0 & 15 & 8 & 1 & 61 \\
\hline 60 to 69 & 8 & 0 & 29 & 0 & 20 & 3 & 0 & 60 \\
\hline 70 and over & 26 & 0 & 18 & 0 & 35 & 11 & 0 & 90 \\
\hline Total & 155 & 3 & 248 & 3 & 86 & 52 & 3 & 550 \\
\hline
\end{tabular}

Table 7: Distribution of pathologies according to age groups. 


\section{Discussion}

Several studies in Africa have been devoted either to an ophthalmologic disease or to the whole of the ocular pathology [6,7]. In Togo as in Africa, few previous studies have been devoted to the question of the profile of eye diseases in general, whether in hospital or not [8-10]. Regarding our study population, it concerns all ages. This corroborates with the methodology adopted in another previous study in Niger [11]. On the other hand, another study carried out in Togo was in a school environment. Thus, depending on the objectives set, the target may or may not be the hospital population. We noted in our study a predominance of the female sex over the male sex. The sex ratio was 0.93 . Our result could be explained by the reluctance of men to consult a doctor in the event of mild symptoms in our study setting where the majority of consultants are rural, and especially by the great availability of women to come for a consultation in the ophthalmology department.

In this study, the reasons for consultation were dominated by reduced visual acuity followed by eye pain and pruritus with $25.55 \%, 25.08 \%$ and $17.14 \%$ respectively. The pre-eminence of visual acuity loss was also found in Eballé's series in Cameroon [9]. On the other hand, in a previous study carried out in Togo, it was rather pruritus that was the first reason for consultation [8]. This difference in the predominance of one functional sign compared to the other is due to the original population, our study concerned all ages, whereas in the pediatric population where ocular pruritus is a frequent reason for consultation.

Our series is dominated by conjunctivitis followed by ametropia and cataract with $45.09 \%, 28.18 \%$ and $15.63 \%$ respectively. Glaucoma represented $9.45 \%$ and came in 4 th position in terms of frequency. A previous study that we carried out in Niger made it possible to find conjunctivitis in the first line. This is also found in other studies carried out in Togo $[8,10]$. On the other hand in Cameroon, in another study, it is ametropia which was in the first line [9]. This reflects the diversity of eye conditions or even their predominance without systematization according to the environment. In all cases, ocular surface conditions seem to be at the forefront. More research was to be devoted to investigating the environmental factors that might attempt to explain these results.

Conjunctivitis represented $45.09 \%$ of cases. All age groups were involved and in different proportions; only the 6 months to 1year age group was less represented here. Diallo [12] on the other hand in Mali found a predominance of ametropia in his study in Kati. Our result is explained by the fact that at this age, newborns are less active and are less in contact with cooking fumes, dust (motorcycle, car, bicycle). In general, this is a pathology that affects all ages, since everyone is exposed to dust. The female predominance is thought to be due to the permanent contact of these women with infected children. Ametropia represented $28.18 \%$ of cases in our study. These figures are close to those found by Diallo [12] in Bamako who found $21.67 \%$. Ametropia was not directly related to age. On the other hand, we recorded a female predominance with $58.06 \%$.

Regarding cataracts, it represented $15.63 \%$ of cases in our study. It is a common pathology whose prevalence increases with age, which is found in all epidemiological studies. The most affected age group in our study was 40 and over. The female sex was especially the most affected because women were more available to be consulted. Glaucoma represented $9.45 \%$ of the pathologies found in this study and the age group 46 years and over was the most affected with $53.85 \%$. The other affections were represented by retinal detachment, eye trauma, pterygium.

\section{Conclusion}

The various ocular pathologies are represented in our series with a ubiquitous distribution. Our study shows that women were more affected than men. The 40 and over age group was the most represented. Conjunctivitis was by far the most frequent pathology, followed by ametropia then cataract with respectively $45.09 \%$; $28.18 \%$ and $15.63 \%$. Both community and hospital actions such as screening and care campaigns are necessary to avoid the economic impact of these pathologies in our communities.

\section{Bibliography}

1. Kimani K., et al. "Prevalence and Causes of Ocular Morbidity in Mbeere District, Kenya. Results of a Population-Based Survey". Plos One 8.8 (2013): e70009.

2. Palmer JJ., et al. "Mapping human resources for eye health in 21 countries of sub-Saharan Africa: current progress towards Vision 2020". Human Resources for Health 12 (2014).

3. Palmer JJ., et al. "Trends and implications for achieving Vision 2020 human resources for eye health targets in 16 countries of sub-Saharan Africa by the year 2020". Human Resources for Health 12 (2014). 
4. Hong H., et al. "The challenge of universal eye health in Latin America: distributive inequality of ophthalmologists in 14 countries". BMJ Open 6 (2016): e012819.

5. Carvalho RS., et al. "Gross domestic product (GDP) per capita and geographical distribution of ophthalmologists in Brazil". Arquivos Brasileiros de Oftalmologia 75 (2012): 407-411.

6. Ayéna KD., et al. "Aspects épidémiologiques et cliniques de la limboconjonctivite endémique des tropiques en milieu rural au Togo". Médecine d'Afrique Noire 5506.6 (2008): 319-324.

7. Koki G., et al. "La limbo-conjonctivite endémique des tropiques au nord Cameroun”. Journal Français d Ophtalmologie 34.2 (2011): 113-117.

8. Vonor K., et al. "Profil des affections oculaires de l'enfant en pratique ophtalmologique au CHU-Tokoin de Lomé (Togo)". Médecine d'Afrique Noire 61.7 (2021): 391-396.

9. Eballe AO., et al. "La pathologie oculaire de l'enfant âgé de 6 à 15 ans: étude hospitalière à Yaoundé”. Cahiers d'étude et de recherche francophone/santé 19.2 (2009): 61-66.

10. Banla M., et al. "Prévalence et causes des principales affections oculaires en milieu scolaire dans la région centrale du Togo". Journal Français d Ophtalmologie 31.1 (2008): 20.

11. Amedome KM., et al. "Profil des affections oculaires chez l'enfant en zone sahélienne : cas de l'hôpital national de Lamorde à Niamey au Niger". Journal de la Recherche Scientifique de l'Université de Lomé 18.2 (2016): 209-215.

12. Diallo S., et al. "Prévalence des affections ophtalmologiques chez les militaires à Kati (Mali)”. Mali Santé Publique 2018 Tome 7.1 (2018): 37-42.

\section{Assets from publication with us}

- Prompt Acknowledgement after receiving the article

- Thorough Double blinded peer review

- Rapid Publication

- Issue of Publication Certificate

- High visibility of your Published work

Website: www.actascientific.com/

Submit Article: www.actascientific.com/submission.php

Email us: editor@actascientific.com

Contact us: +919182824667

Citation: Kokou Messan Amedome., et al. "Prevalence of Ocular Diseases at University Teaching Hospital of Kara in Togo". Acta Scientific Ophthalmology 5.2 (2022): 04-08. 